\title{
After the Death of Charismatic Authority: A Weberian Perspective on Early Islam
}

\section{MOHAMMAD SYIFA AMIN WIDIGDO}

Universitas Muhammadiyah Yogyakarta

\section{ABSTRACT}

In Max Weber's notion of authority, charismatic authority will transform into other forms of either traditional authority, rational authority, or both. After the death of charismatic leader, in Weber's word, charismatic authority is "fated to decline." A number of studies on Weber and Islam seem to affirm Weber's thesis regarding the decline of charismatic authority after the death of the charismatic leader. However, in the context of early Islam, charismatic authority is not declining, even reinforced after the death of the charismatic leader, namely Prophet Muhammad. Therefore, this paper aims to show why charismatic authority after the death of charismatic leader is not waning in the early Islam and how such authority is even reinforced. By using Alasdair McIntyre's theory of human vulnerability, this paper investigates "material and ideal interests" of Muslims after the death of the Prophet, which make charisma of the prophet not declining, even more strengthened through invocations and venerations by his followers in subsequent generations. In this regard, the return of charismatic authority takes place not in the physical form of charismatic leader, but in the forms of images, sayings, and exemplary practices of the deceased charismatic leader, which are deemed worth emulating and invocation.

Keyword: Charismatic Authority, Weberian Perspective, Islam.

\section{ABSTRAK}

Dalam konsep otoritas Max Weber, otoritas kharismatik akan berubah menjadi otoritas tradisional, rasional, atau keduanya. Setelah kematian seorang pemimpin kharismatik, menurut Weber, otoritas kharismatiknya "ditakdirkan akan menurun.” Beberapa studi yang dilakukan tentang hubungan antara pemikiran Weber dan Islam sepertinya mengafirmasi tesis Weber tentang menurunnya otoritas kharismatik setelah kematian seorang pemimpin kharismatik. Namun demikian, dalam konteks studi Islam awal, otoritas kharismatik bukan menurun, 
malah makin menguat setelah kematian seorang pemimpin kharismatik, yang nota bene adalah Nabi Muhammad. Oleh sebab itu, paper saya bertujuan untuk menunjukkan mengapa otoritas kharismatik pada masa Islam awal tidak melemah dan bagaimana otoritas tersebut bahkan dibuat makin kuat. Dengan menggunakan teori kerentanan manusia oleh Alasdair McIntyre, paper saya berusaha menelisik "kepentingan-kepentingan ideal dan material" yang dimiliki kaum Muslimin setelah wafatnya Nabi, yang membuat kharisma Nabi tidak melemah, justru menguat melalui penghormatan kepadanya dan penyeruan nama serta ingatan terhadapnya oleh para pengikut di generasi-generasi berikutnya. Dalam hal ini, kembalinya otoritas kharismatik terjadi tidak dalam bentuk kembalinya fisik pemimpin kharismatik, melainkan dalam bentuk citra, kumpulan perkataan, dan tauladan tindakan yang layak untuk ditiru dan diingat-ingat dari sang pemimpin kharismatik yang telah meninggal itu.

Kata Kunci: Otoritas Kharismatik, Otoritas Tradisional, Islam.

\section{INTRODUCTION}

"In its pure form, charismatic authority may be said to exist only in the process of originating. It cannot remain stable, but becomes either traditionalized or rationalized, or combination of both."(Max Weber 1964, 364)

The fate of charismatic authority after the death of its charismatic founder seems to be in danger. The pure form of this authority which emerges in the initial formation of authority can disappear. When the holder of the pure form of charismatic authority deceases, according to Weber, the authority will undergo the process of "routinization" "and turn into another kind of legitimate authority; either traditional, legal-rational, or a combination of both. ${ }^{2}$ This compelling theory of authority interestingly inspires scholars of Islam to study the phenomena of authority in Islamic tradition. In spite of a severe criticism of Weber's remark on Islam, which is accused to be inaccurate ${ }^{3}$, incomprehensive and Eurocentric ${ }^{4}$, his sociological conception of authority gains a positive response. There are numbers of study which are informed or influenced by Weber's notion of authority. Hamid Dabashi (1989) shows the transformation of charismatic authority in early Islam on the basis of Weber's accounts. He finds that the charismatic authority is apt to be perpetuated or institutionalized in different modes of authority along with types of the followers. ${ }^{5}$ In a similar fashion, Jonathan E. Brockopp (2005) emphasizes his study on the role of followers and their texts by means of which a new-dynamic model of charismatic authority can be derived. ${ }^{6}$ By presenting numerous works on 
religious authority topics, in addition, Gudrun Kramer and Sabine Schmidtke (2006) intend to extend Weber's notion of authority into a wider scope. The authority for them is ascribed not only to individuals, but also groups of people and institutions. ${ }^{7}$

Although these studies successfully describe the modes of transformation of authority after the death of the charismatic leader, the roles of the followers, and the scopes of authority in Islamic tradition, the underlying reasons why charismatic authority needs be institutionalized are missed. The routinization of authority is apparently deemed automatic and natural without human motives and deliberations. Max Weber actually indicates that the motives behind the transformation of charisma are "the ideal and material interests of the followers." ${ }^{8}$ With the aid of Alasdair Mclntyre's theory of human dependence ${ }^{9}$, in fact, this paper first aims to identify what "the ideal and material interests" of early Muslims are. After the reasons of the routinization of charisma are identified, the second objective is to show that charismatic elements of the charismatic leader are not "fated to decline" 10 as Weber claims. Although the process of the institutionalization of charisma increasingly develops, they can be more apparent and powerful because of the pervading invocation or association of the followers with the charismatic leader.

\section{HUMAN VULNERABILITY}

Inspired by Alasdair Mclntyre, first, we will investigate the motives behind the institutionalization of charismatic authority in the early Islamic society. Mclntyre maintains that human beings are full of vulnerability, such as vulnerability of being afflicted by bodily illness and injury, inadequate nutrition, mental defect and disturbance, and human aggression and neglect. ${ }^{11}$ To cope with these vulnerabilities, according to Mclntyre, human beings need "particular others". The role of others is to help vulnerable people in obtaining needed resources, to help them discover what new ways forward there may be, and to stand in their place from time to time, doing on their behalf what they can not do for themselves. ${ }^{12}$ For Mclntyre, this kind of dependence on others is most obvious in early childhood and in old age, and is possible to occur between the first and the last stage of lives when one is afflicted with certain injury, illness, or disability. ${ }^{13}$ In this context, parents, teachers, trainers, proxies, friends, and a wider network of social relationships can play an important role. They - 
which can be interpreted as agents of authority because of their capacity in both issuing directive aids and rendering certain obedience- can provide necessary aids in order to flourish.

McIntyre's concept of human vulnerability and dependence mentioned above inspires us to think of vulnerability of human beings as social entity. In this light, the scope of individual vulnerability is extended into understanding of vulnerability in a social context. It means that if a person can suffer from bodily illness, brain damage, or mental retardation; similarly, a society is also susceptible of being divided, disorder, chaotic, and fallen into a long period of civil wars. In the line of this argument, if a personal vulnerability can be confronted with the aid of "particular others", a society needs "particular others" as well in order to deal with its vulnerability.

In the case of early Islamic society, a sort of societal vulnerabilities took place after the death of the prophet (Muhammad) in 632. Among those vulnerabilities are: one, Bedouin tribes that had submitted to Muhammad refused to do their obligations, such as sending zakâh (religious alms) to Medina. Two, an apostasy movement (riddah) was increasing because of the absence of the prophet. Three, a false prophet emerged with a claim of conveying a new message and revelation. Four, a sectarian rivalry for leadership occurred, especially between the Ansar, the Muslims from Medina, and the Muhâjirûn, Muslims emigrated from Mecca. ${ }^{14}$ Five, the advocates of Muhammad's family and the elderly companions of Muhammad were disputing the right of political and religious leadership. The former claimed that Muhammad appointed Ali b. Abi Talib (Muhammad's son in law and also his cousin) as a leader after him; while the later refused such claim. The elder companions gathered and elected Abu Bakar as the subsequent leader of the community.

These vulnerabilities make the early Muslims realizing that they can not stand alone. They need "particular others" to help them in confronting the imminent social division and disintegration, which indeed could lead to the destruction of the ummah (Islamic society). Unlike "particular others" of McIntyre which consist of personal agents, "particular others" in early Islam seem to be less personal, namely: a collective memory of examples, values, and teachings of the prophet. In turn, they invoke those examples, values and teachings of the prophet with the interests of maintaining and strengthening Islamic social order (Weber may call them "material interests"). At the same time, they submit themselves to the pro- 
phetic traditions with the intentions of making the charismatic authority of the prophet keeps alive and respected (In Weber's term, it would be called "ideal interests"). Those are the reasons of why the routinization of charisma occurs in early Islamic society. Interestingly, there is a kind of mutual symbiosis here; on the one hand, the charismatic authority is always invoked and preserved in order to prevent social disintegration and to build a more solid civilization; on the other hand, the image and influence of charismatic authority itself is getting more powerful because of the continuous invocation.

\section{ROUTINIZATION: A DECLINE OR INTENSIFICATION OF CHA- RISMA?}

Routinization of charisma is signified by the process of disassociation of authority from a personal quality of the charismatic leader and of the embodiment of authority in an objective institutional structure. ${ }^{15}$ Max Weber believes that such routinization will eventually end up in the process of traditionalization, rationalization, or both of them. ${ }^{16}$ However, as the process of the routinization begins to develop, charisma starts to decline because its character turns into more impersonal, ordinary, and routinized. ${ }^{17}$ "It is the fate of charisma," Weber argues," to recede before the powers of tradition or of rational association after it has entered the permanent structures of social action." ${ }^{18}$ For Weber, the waning of charisma is inevitable. A charisma will be melted in the process of routinization and disassociated from the charismatic leader. A prophetic charisma, for example, will be transformed into a church, sect, or cult which engenders dogma, doctrine, orthodoxy, law, or petrified tradition.

According to Weber, disciples, followers, or companions of the charismatic figure play a significant role in the process of routinization and thus declining of charisma. They not only possess ideal motives of routinization, such as a voluntary devotion to the calling of prophet, but also material interests of it such as desires for gaining benefices, official positions, fiefs, or booties. ${ }^{19}$ Only a small number of followers would devote their lives purely and idealistically to their call. A majority of them want to live off their calling in material interests as well. ${ }^{20}$ It seems to me that the desire for gaining material interest is greater than for the ideal one; therefore, the decline of charisma is plausible.

Weber's elucidation of routinization of charisma which suggests the 
important role of companions and loyal followers in establishing authority is apparently confirmed by historical accounts of early Muslims. However, the routinization of charisma in Islamic context seems to not engendering the decline of charisma, rather, intensifying invocation of charisma. In the initial development, the authority was centered upon the prophet who received respect and obedience because of conveying God's revelation (Quran) and showing exemplary behaviors (Sunnah). After the death of prophets, in fact, those companions (sahabah) and followers (tabi'în) of the prophet (tabi'în) attempted to maintain charismatic authority of the prophet through several ways. Among the ways of preserving of such authority are by electing the leader of community of believers (khalifah), then enacting certain moral codes based on the prophetic teachings and examples (sunnah), and eventually forming religious orthodoxy (sharîah). The charismatic authority is then transformed into the path of traditionalization and rationalization.

The first generation of the companions, under the leadership of Abu Bakr (632-634), Umar b. Khatab (634-644), Uthman b. Affan (644-656), and Ali b. Abi Talib (656-661), was relatively successful in terms of paving away for early institutionalization of charisma. Although there were occasions in which charismatic authority of the prophet was threatened by an apostasy movement (riddah), series of caliphs' murder, a civil war, and a social discontent (fitnah), charisma of the prophet Muhammad was generally not waning. His charismatic authority was indeed more efficacious, in the sense that his authority was intensely invoked in the interests of spreading Islam and of building a more solid civilization. Companions generally invoke charismatic authority of the prophet in two ways; first, relying on the messages and teachings of the Quran which were conveyed and taught by Muhammad; second, emulating Muhammad's exemplary behavior and conducts (Sunnah or Hadith).

Besides sending military forces to tackle apostasy movements of Arab Bedouins and to launch raids against the Sasanian and Byzantine Empire, for example, Abu Bakr (632-634) was also sending "Qur'an-reciters". ${ }^{21}$ The role of these Qur'an-reciters was to teach the essentials of Islamic faith, including introducing exemplary practices of Muhammad. Interestingly, in the period of Umar b. Khattab (634-644), this policy to was continued. The teachers of the Quran were deployed in addition to appointing military commanders-cum-administrators into Islamic garrison towns 
(anzâr). ${ }^{22}$ At that time, these Quran-teachers, commanders, and their administrative assistants (i.e. proto-qâdis/proto-Islamic judge) played an important role in terms of promulgating Islam as new religion based on the Quran and the Sunnah. ${ }^{23}$ They not only taught Quran-values and the exemplary practices of the Prophet, but also erected a mosque, led a Friday prayer, distributed booty pensions, commanded military campaigns, and resolved conflicts among tribesmen. ${ }^{24}$ In this light, what Weber calls "the ideal and material interests of institutionalization of charisma" was apparently met; and at the same time, a kind of fusion of traditionalization and rationalization of charisma was seemingly achieved.

The process of routinization of charisma was more apparent in the era of Uthman b. Affan (644-656). Uthman initiated compilation of al-Quran which was previously available in fragmentary sources. There were initially parts of the Quran which written down on parchment, shoulder blade, or stones; and others were memorized by some companions of the prophet. On the basis of these fragmentary sources, Uthman commissioned Zayd b. Thabit to undertake the task of compiling a standard text of the Quran. Several copies of this text were made and later distributed to the garrison towns, all other previous collections having reportedly been destroyed. ${ }^{25}$ This official version of the Qur'an was made clearly in the intention of preserving religious faith as a spiritual foundation for Islamic order.

At the time of Ali b. Abi Talib (656-661), however, Islamic social order was tested by a sequence of civil wars and social disruptions. In the beginning of his leadership, the prophet's influential widow, Aishah, and other two respected companions, Talhah and Zubair, launched military opposition from Basra and Kufa. Ali successfully handled them. The second and more dangerous opposition was coming from Syria which led by Mu'awiyah. Actually, this military opposition could also be defeated by Ali. But, when Mu'awiyyah requested for a peaceful arbitration in his imminent defeat, Ali approved it. Ali then faced disappointed results. After a long process of arbitration, Ali was eventually forced to accept its results which were in favor of Mu'awiyyah's side; one, condemning the mutineer of Uthman (which means condemning Ali who not punished those mutineers) ${ }^{26}$; second, the necessity of electing a new caliph. ${ }^{27}$ Triggered by this political turbulence, Islamic community was in turn divided into at least three groups; first, some of Ali's supporters who disserted and estab- 
lished a new religious-political movement, namely Khawarij; second, Ali's supporters who remained loyal to Ali, namely Shi'ah; third, supporters of Mu'awiyyah and majority of Muslims who were abstain regarding the result of arbitration, which later became Sunni. ${ }^{28}$

In spite of long series of political turbulence, there were still generations of companions and followers prophets who strived to restore and protect Islamic social order by means of appealing to the prophetic traditions. They believed that if the memory of the prophet was kept alive in the mind of Islamic community, a new social cohesion could be restored. Their basic assumption is that Islamic social cohesion was generally based upon the "collective concept the followers had of him."29

After the above civil war and political instability, there were agents who felt themselves responsible for protecting and perpetuating the prophetic traditions. Among them are; religious scholars ('ulamâ') including Quran-interpreters and teachers (mufassirûn) and Hadith scholars (muhaddithûn) and religious ascetics (sûfî). Ira M. Lapidus records that these religious scholars ('ulamâ') tended to conceive of the Prophet's legacy in terms of correct Muslim behavioral in ritual, family, commercial, and indeed in all of life's concerns. Meanwhile, Muslim ascetics moved away from religious rituals and social practices to the inward cultivation of the moral and religious qualities which brought an individual closer to the spiritual quality of Muhammad and thereby to the divine being. ${ }^{30}$

According to Lapidus, the authority of both religious scholars and ascetics was reinforced by a chainlike tradition of learning which its source could be traced back to the authority of the Prophet. He describes such chainlike transmission of authority and knowledge in the following: "The scholars of each generation, having acquired their knowledge from a chain of predecessors going back to the Prophet passed on their knowledge to their successors. Though religious knowledge was confided to books, the chain of transmission was oral. The textual knowledge had to be communicated by a living master who gave book learning spiritual meaning. Similarly, the spiritual exercises of the Sufis were passed on from generation to generation and were assumed to be part of a chain of succession which went back to Muhammad. Muslim religious authority then combined acquired personal knowledge or spiritual insight with direct personal contact across the generations with the Prophet himself." ${ }^{11}$ In the hand of these religious scholars and Muslim ascetics, charismatic authority of the 
prophet is continuously referred as a source and guidance of daily routines. Islamic jurists (fuqahâ') and Islamic judges (qâdîs), for instance, always attempt to look for precedents and traditions of the prophet before they issue religious or legal rulings (fatâwâ). Islamic mystics and ascetics (cûfîs) always recite supplications praising the Prophet in order to attain spiritual disclosures (kashf). Qur'an-scholars (mufassirûn) also need to invoke the traditions of the Prophet in order to have a better interpretation of the Quran through identifying occasions of revelation (asbâb al-nuzûl). Indeed, the most important source to know prophetic traditions besides the biography of the Prophet (sirah) and stories (akhbâr) is a collection of the Prophet's sayings, deeds, behaviors, and decrees (hadith). The collectors and scholars of the Prophetic traditions (muhaddithûn) apply a very strict method to ensure that the hadiths they collected can be traced back to the Prophets without defects and interruptions in their chain of transmission.

In brief, although charismatic authority of the Prophet has been routinized, traditionalized, rationalized, and even tested by series of political and social discontents, a continuous invocation of prophetic traditions in the intention of preserving religion and maintaining Islamic social order renders charisma of the Prophet more intensified rather than declined. Therefore, unlike Weber's claim, charisma of the charismatic leader in the case of Islam is perpetuated and intensified rather than declining and disappearing.

\section{CONCLUSION}

As can be seen from the above explanation, early Muslims realize that they have what Mclntyre calls "vulnerability" as a community; ranging from political turbulences (e.g. the rise and fall of the caliphs), social divisions (e.g. military oppositions from Bedouins), to cultural disintegrations (e.g. an enmity among tribes). To handle these vulnerabilities, they invoke and emulate exemplary practices and conducts (Sunnah) of the Prophet Muhammad. They believe that a collective memory of Muhammad's individual charisma and of his exemplary traditions can render Islamic social cohesion. Thus, the material interests of routinization of charisma in early Islam are mainly centered upon the intention of confronting the above social vulnerabilities. Meanwhile, the ideal interests of it are centered upon the aims of emulation and devotion to the traditions of the Prophet. In- 
terestingly, the acts of invoking the prophetic traditions itself become the primary means of confronting the social vulnerabilities.

Such mutual symbiosis between the ideal and material interests seems to be the reasons why routinization in early Islam renders intensification instead of waning of charisma. Charismatic authority of the Prophet is not "fated to decline" as Weber claims. Instead, charisma of the Prophet is more intensified and powerful because of pervading invocation of his exemplary traditions. Although political and social situations in early Islam are shaky and instable, the desire of early Muslims to associate themselves with the Prophet is not waning. In fact, their invocation and emulation of prophetic practices are aimed to maintain a social stability and to establish a more solid social cohesion among Muslims. The important actors behind such invocation of prophetic traditions are companions (sahabat), followers (tabi in), commander-cum-administrators (proptoqadis), judges (qadis), and ascetics (Sufis), and religious scholars (ulama) ranging from Quran-interpreters (mufassirun), Islamic jurists (fuqaha), and more importantly, collectors and scholars of prophetic traditions (muhadditsun).

\section{ENDNOTES}

1 In the process of routinization, charismatic elements of authority will be disassociated from the person of individual leader and embodied in an objective institutional structure. See Talcott Parsons, "The Institutionalization of Authority," Introduction to The Theory of Social and Economic Organization, by Max Weber (New York: The Free Press, 1964), p. 67.

2 Weber differentiates what he calls "legitimate authority" into three categories: rational-legal authority, traditional authority, and charismatic authority. The first authority relies on the efficacy of normative rules and legal aspects in issuing command and engendering obedience, the second type rests on an established belief in the sanctity of traditions, and the last one lies on the devotion to a charismatic person who is obeyed by virtue of personal trust in him and his revelation. See Max Weber, The Theory of Social and Economic Organization, p. 328.

3 Bryan S. Turner, Weber and Islam, (London: Routledge \& Kegan Paul 1974), p. 2.

4 Wolfgang Schluchter, "Hindrances to Modernity: Max Weber on Islam," in Max Weber $\mathcal{E}$ Islam, ed. Toby E. Huff and Wolfgang Schluchter (New Jersey: Transaction Publishers: 1999), p. 64.

5 Hamid Dabashi, Authority in Islam, (New Jersey: Transaction Publishers, 1989).

6 Jonathan E. Brockopp, "Theorizing Authority in Early Islamic Law," Com- 
parative Islamic Studies 1.2 (2005): p. 129-158.

7 Gudrun Kramer and Sabine Schmidtke, ed., For Islam: Religious Authorities in Muslim Societies, (Leiden: Brill, 2006).

8 Max Weber, The Theory of Social and Economic Organization, (New York: The Free Press, 1964), p. 364.

9 Instead of merely recognizing the reality of 'goal-based human dependence', McIntyre identifies a kind of dependence which results from human susceptibility and suffering which is all often ignored, See Alasdair McIntyre, Dependent Rational Animal: Why Human Beings Need the Virtues, (2005), p. 2-3

10 Max Weber, The Nature of Charismatic Domination, p. 248.

11 Alasdair McIntyre, Dependent Rational Animal: Why Human Beings Need the Virtues, (Chicago: Open Court, 2005), p. 1.

12 Ibid., p. 73.

13 Ibid.,p. 1.

14 Marshall G.S. Hodgson, The Venture of Islam, Volume One, (Chicago: The University of Chicago, 1974), p. 197.

15 Parsons, p. 67.

16 Max Weber, Economy and Society: An Outline of Interpretive Sociology, ed. Guenther Roth and Claus Wittich (Berkeley: University of California Press, 1963), p. 246.

17 Ibid., p. 1133.

18 Ibid., p. 1148.

19 Max Weber, The Theory of Social and Economic Organization, p. 368.

20 Ibid., p. 367.

21 Marshal G.S. Hodgson, p. 199.

22 Wael B. Hallaq, The Origins and Evolution of Islamic Law, (Cambridge: Cambridge University Press, 2005), p. 31.

23 The idea of Sunnah of the Prophet was in fact firstly used in this period, especially when the Muslims commander, namely Yazid b. Abi Sufyan, declared that he was ordered to head for Palestinian town of Qisariyya in order to take it "and to call the people of that area to the Book of God and the Sunnah of His Messanger." (see Wael B. Hallaq, p. 48.

24 Ibid.

25 Ibid, p. 33.

26 Marshal G.S. Hodgson, Ibid,p. 216.

27 Hans Kung, Hans Kung Islam: Past, Present, \& Future, (Munich: A Oneworld Book, 2007), p. 185.

28 Ibid., p. 185-186.

29 G.H.A Juynboll, Muslim Tradition, (Cambridge: Cambridge University Press, 1983), p. 9.

30 Ira M. Lapidus, "The Institutionalization of Early Islamic Societies," in Huff, Tobby E. and Wolfgang Schluchter, eds. 1999. Max Weber Eु Islam. New Jersey: Transaction Publishers, p. 143-144.

31 Ira M. Lapidus, p. 144-145. 


\section{BIBLIOGRAPHY}

Brockopp, Jonathan E. 2005. “Theorizing Authority in Early Islamic Law.” Comparative Islamic Studies 1.2:

Dabashi, Hamid. 1989. Authority in Islam. New Jersey: Transaction Publishers.

Hallaq, Wael B. 2005. The Origins and Evolution of Islamic Law. Cambridge: Cambridge University Press.

Hodgson, Marshal G.S.. 1974. The Venture of Islam (1). Chicago: The University of Chicago Press.

Huff, Tobby E. and Wolfgang Schluchter, eds. 1999. Max Weber Ë Islam. New Jersey: Transaction Publishers.

Juynboll, G.H.A. 1983. Muslim Tradition. Cambridge: Cambridge University Press.

Kramer, Gudrun and Sabine Schmidtke, eds. 2006. For Islam: Religious Authorities in Muslim Societies. Leiden: Brill,.

Kung, Hans. 2007. Hans Kung Islam: Past, Present, and Future. England: A Oneworld Publication.

Lapidus, Ira M. "The Institutionalization of Early Islamic Societies," in Huff, Tobby E. and Wolfgang Schluchter, eds. 1999. Max Weber EI Islam. New Jersey: Transaction Publishers

McIntyre, Alasdair. 2005. Dependent Rational Animal. Illinois: Open Cort.

Parsons, Talcott. 1964. "The Institutionalization of Authority," Introduction to The Theory of Social and Economic Organization, by Max Weber. New York: The Free Press,

Schluchter, Wolfgang. 1999. "Hindrances to Modernity: Max Weber on Islam," in Max Weber Eु Islam, ed. Toby E. Huff and Wolfgang Schluchter. New Jersey: Transaction Publishers.

Turner, Bryan S. 1974. Weber and Islam. London: Routledge \& Kegan Paul.

Weber, Max. 1964. The Theory of Social and Economic Organization. New York: The Free Press,.

Weber, Max. 1963. Economy and Society: An Outline of Interpretive Sociology, ed. Guenther Roth and Claus Wittich. Berkeley: University of California Press. 